University of Nebraska - Lincoln

DigitalCommons@University of Nebraska - Lincoln

\title{
Ecology of common salvinia, Salvinia minima Baker, in southern Florida
}

\author{
Philip W. Tipping \\ USDA-ARS, Philip.tipping@ars.usda.gov \\ Melissa R. Martin \\ USFWS \\ Laurie Bauer \\ National Ocean Service \\ Ryan M. Pierce \\ Alan Plummer Associates \\ Ted D. Center \\ USDA-ARS
}

Follow this and additional works at: https://digitalcommons.unl.edu/usdaarsfacpub

Tipping, Philip W.; Martin, Melissa R.; Bauer, Laurie; Pierce, Ryan M.; and Center, Ted D., "Ecology of common salvinia, Salvinia minima Baker, in southern Florida" (2012). Publications from USDA-ARS / UNL Faculty. 1406.

https://digitalcommons.unl.edu/usdaarsfacpub/1406

This Article is brought to you for free and open access by the U.S. Department of Agriculture: Agricultural Research Service, Lincoln, Nebraska at DigitalCommons@University of Nebraska - Lincoln. It has been accepted for inclusion in Publications from USDA-ARS / UNL Faculty by an authorized administrator of DigitalCommons@University of Nebraska - Lincoln. 


\title{
Ecology of common salvinia, Salvinia minima Baker, in southern Florida
}

\author{
Philip W. Tipping ${ }^{\mathrm{a}, *}$, Melissa R. Martin ${ }^{\mathrm{b}}$, Laurie Bauer ${ }^{\mathrm{c}}$, Ryan M. Pierce ${ }^{\mathrm{d}}$, Ted D. Center ${ }^{\mathrm{a}}$ \\ a USDA-ARS Invasive Plant Research Laboratory, Davie, FL, USA \\ b USFWS, A.R.M. Loxahatchee National Wildlife Refuge, Boynton Beach, FL, USA \\ ${ }^{\mathrm{c}}$ National Ocean Service, Center for Coastal Monitoring and Assessment, Silver Spring, MD, USA \\ ${ }^{\mathrm{d}}$ Alan Plummer Associates, Inc., Dallas, TX, USA
}

\section{A R T I C L E I N F O}

\section{Article history:}

Received 21 October 2011

Received in revised form 3 April 2012

Accepted 13 April 2012

Available online 25 April 2012

\section{Keywords:}

Salvinia minima

Interspecific competition

Disturbance

Herbivory

Population dynamics

\begin{abstract}
A B S T R A C T
Populations of the floating macrophyte, Salvinia minima Baker, were assessed over a 39-month period at four sites in southern Florida in order to elucidate the abiotic and biotic factors that influenced their density. These factors included the abundance of other plant species, changes in water depth, water quality, and herbivory by insects. Abiotic factors like temperature, $\mathrm{pH}, \mathrm{DO}$, and conductivity varied among sites and, more importantly, over time. The same was true for S. minima biomass, coverage, and condition. Principal component analysis identified four components which together explained 64\% of the variability in S. minima biomass. The first component correlated strongly with herbivory from Cyrtobagous salviniae Calder and Sands and Synclita obliteralis (Walker) as well as the abundance of the duckweed Spirodela polyrrhiza (L.) Schleid. Temperature effects were strongly represented in the second principal component. A stepwise regression model that best predicted $S$. minima biomass incorporated conductivity, insect herbivory, and interspecific plant abundance. Broader dry vs. wet season influences were apparent and linked to temperature, water depth, and conductivity that covaried with S. minima biomass. Sites where water depth changed the most had the least $S$. minima. Insect herbivory did not increase under more stagnant conditions when plant populations were less mobile. Overall, S. minima populations cycled in southern Florida in response to a shifting array of abiotic and biotic factors. The relative importance of these factors was less clear although the influences of herbivory, temperature, and the presence of other plants were significant.
\end{abstract}

Published by Elsevier B.V.

\section{Introduction}

Herbivory, competition, water quality, hydrology, and their interactions contribute to the structuring of aquatic plant communities (Webb et al., 2006; Harpole and Suding, 2007; Grime, 1973; Tipping et al., 2009). Floating macrophytes in particular experience dynamic forces that are unique among plants, namely a movable substrate whose habitat location, nutrient profile, depth, current, and competing vegetation can change rapidly and unpredictably. These forces likely interact simultaneously along a continuum of temporal and spatial levels and their relative contribution is probably context-specific. For example, in a highly disturbed site where water levels and currents are more dynamic, factors like herbivory and nutrients may interact differently than in stagnant water.

This study assessed in situ stands of common salvinia, Salvinia minima Baker, at specific sites in southern Florida with the aim of elucidating the biotic and abiotic factors that influenced its

\footnotetext{
* Corresponding author. Tel.: +1 954475 6547; fax: +1 9544769169. E-mail addresses: Philip.tipping@ars.usda.gov, ptipping@saa.ars.usda.gov (P.W. Tipping).
}

population dynamics. We hypothesized that top-down effects like herbivory by specialist herbivores such as Cyrtobagous salviniae Calder and Sands (Coleoptera: Curculionidae), along with generalists like Samea multiplicalus (Guenée) (Lepidoptera: Pyralidae) and Synclita obliteratis (Walker) (Lepidoptera: Pyralidae), would be a primary factor in regulating $S$. minima.

\section{Materials and methods}

\subsection{The study plant}

Salvinia minima is an exotic floating macrophyte common to freshwater drainages in Florida. Native to Central and South America, this species was probably introduced into the U.S. through the aquarium trade (Stoltze, 1983; Mickel and Beitel, 1988). It was first reported in Florida in the St. Johns River in 1928 and currently inhabits a wide range of fresh water natural and man-made habitats including sloughs, cypress swamps, lakes, and canals under a continuum of shading conditions (Small, 1931). Jacono et al. (2001) documented the spread of this species throughout Florida and along the Gulf coast. Although this species is considered noxious in several states, its pest status in Florida is relatively minor compared 
Table 1

Locations and descriptions of experimental sites in southern Florida with persistent populations of S. minima.

\begin{tabular}{|c|c|c|c|c|}
\hline Name & GPS & Habitat & Associated aquatic plants & Area $\left(\mathrm{km}^{-2}\right)$ \\
\hline $\begin{array}{l}\text { Loxahatchee } \\
\text { Visitors Center }\end{array}$ & $\begin{array}{l}26^{\circ} 29^{\prime} 58.10^{\prime \prime} \mathrm{N} \\
80^{\circ} 12^{\prime} 45.08^{\prime \prime} \mathrm{W}\end{array}$ & Pond & Spirodela polyrrhiza (L.) Schleid. & 0.002 \\
\hline $\begin{array}{l}\text { Corkscrew Swamp } \\
\text { Sanctuary }\end{array}$ & $\begin{array}{l}26^{\circ} 22^{\prime} 33.09^{\prime \prime} \mathrm{N} \\
81^{\circ} 36^{\prime} 32.05^{\prime \prime} \mathrm{W}\end{array}$ & Slough & $\begin{array}{l}\text { Limnobium spongia (Bosc.) Steud. } \\
\text { Azolla caroliniana Will., Thalia geniculata } \\
\text { L., Polygonum punctatum Ell. }\end{array}$ & 20.0 \\
\hline $\begin{array}{l}\text { Fisheating } \\
\text { Creek }\end{array}$ & $\begin{array}{l}26^{\circ} 55^{\prime} 51.44^{\prime \prime} \mathrm{N} \\
81^{\circ} 18^{\prime} 52.78^{\prime \prime} \mathrm{W}\end{array}$ & Oxbow & Eichhornia crassipes (Mart.) Solms. & 0.05 \\
\hline $\begin{array}{l}\text { Loxachatchee } \\
\text { Swamp }\end{array}$ & $\begin{array}{l}26^{\circ} 29^{\prime} 55.64^{\prime \prime} \mathrm{N} \\
80^{\circ} 12^{\prime} 51.36^{\prime \prime} \mathrm{W}\end{array}$ & $\begin{array}{l}\text { Swamp } \\
\text { Forest }\end{array}$ & Pistia stratiotes L., A. caroliniana & 1.5 \\
\hline
\end{tabular}

with states like Louisiana where the plant is considered a significant problem. One difference between these states is the presence of the specialist herbivore $C$. salviniae in Florida. This weevil was first detected in 1962, although it may have been present earlier, and was probably introduced along with the plant (Kissinger, 1966).

\subsection{Sampling method}

Four field sites were monitored monthly from April 2002 through July 2005: (1) Fisheating Creek (FEC), (2) the Audubon Corkscrew Swamp Sanctuary (Cork), and two sites in the Arthur R. Marshall Loxahatchee National Wildlife Refuge: (3) Visitors Center (LoxVC) and (4) Loxahatchee Swamp (LoxSW). The habitats ranged from natural sloughs to oxbow lakes that contained persistent populations of S. minima (Table 1 ).

Sites were visited once a month and three samples from each of four permanent transects were collected within each site. These transects were established using landmarks and GPS. Sampling of plant cover and biomass was conducted using $0.1 \mathrm{~m}^{2}$ floating pvc frames placed haphazardly within transects. Plant coverage by all species within the sample frames was estimated visually to the nearest $10 \%$ by two observers. Brown coloration of S. minima mats has been associated with insect-damaged and weakened plants as with S. molesta (Room et al., 1981), so a visual estimate was also made of the percentage of the $S$. minima mat that appeared green vs. brown, estimated to the nearest $25 \%$ within the ranges of 0 , $1-24,25-49,50-74,75-99$, and $100 \%$. All the S. mimima was then collected from the samples and first processed through a Berlese funnel for $72 \mathrm{~h}$ to force out herbivorous insects into collection jars stocked with a few live $S$. minima plants. The number and weights of adult $C$. salviniae were recorded and a subset of adults was sacrificed to check for the presence of microsporidia. No biomass or pathogen measurements were taken from other herbivores on S. minima or other plant species. Plant samples were dried to a constant weight to obtain dry weight biomass. Whole plants were used to determine the carbon and nitrogen concentration in live tissues with a CHN analyzer. The leaf size of S. minima was estimated by haphazardly selecting 10 ramets per transect and measuring the length of the long axis of two leaves at the second internode proximal from the apical bud of each ramet. Water depth, $\mathrm{pH}$, water temperature, DO, and conductivity were recorded in sample squares using a variety of hand-held meters. Air temperature was measured at the first transect of each site.

Principal components analysis was used to characterize the variation in the sample data. Variables that appeared to influence $S$. minima biomass were further subjected to forward stepwise regression. The influence of several variables was also directly examined using repeated measures ANOVA. Variable means were separated post hoc using Tukey's HSD or $t$-tests. All statistical analyses were conducted using SAS v9 (SAS, 2000).

\section{Results}

There were substantial differences in S. minima biomass, \% coverage, and \% green among sites and over time (Table 2). The influence of date (time) was the most important while the influence of transects was insignificant. There was also a significant site $\mathrm{x}$ date interaction for all the variables (Table 2). Abiotic factors like water temperature, water quality, and the change in water depth between samples also varied among sites (Table 3). Nitrogen levels, as measured in S. minima tissue, did not differ among sites, ranging from $2.25 \%$ to $2.32 \%$ of DW. The smallest weevils were found at Cork and LoxSW $(0.67 \pm 0.01 \mathrm{mg}$ and $0.70 \pm 0.02 \mathrm{mg}$, respectively) and the largest at FEC and LoxVC $(0.76 \pm 0.02 \mathrm{mg}$ for both sites).

Combining all variables from all field sites yielded four principal components with each accounting for at least $8 \%$ of the variation, while cumulatively accounting for $64 \%$ of the total variability (Table 4). The first principal component explained $26 \%$ of the total variance and was interpreted as complex of factors related to insect herbivory and the abundance of small floating plants found in the same niche as S. minima. The second principal component explained $14 \%$ of the variation and reflected the influence of

Table 2

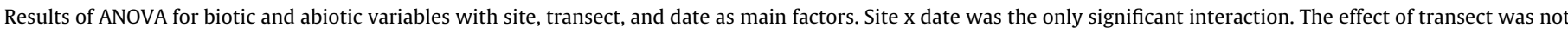
significant except for depth $(\mathrm{df}=3$, TSS $=4 \%, P=0.001)$.

\begin{tabular}{|c|c|c|c|c|c|c|c|c|c|}
\hline \multirow[t]{2}{*}{ Variables } & \multicolumn{3}{|c|}{ Site } & \multicolumn{3}{|c|}{ Date } & \multicolumn{3}{|c|}{ Site $\times$ Date } \\
\hline & df & TSS (\%) & $P$ & df & TSS (\%) & $P$ & df & TSS (\%) & $P$ \\
\hline Total biomass ( $\mathrm{g} \mathrm{DW} \mathrm{m}^{-2}$ ) & 3 & 5 & 0.001 & 30 & 24 & 0.001 & 90 & 39 & 0.001 \\
\hline Percent cover $\left(\mathrm{m}^{-2}\right)$ & 3 & 3 & 0.001 & 30 & 29 & 0.001 & 90 & 38 & 0.001 \\
\hline Percent green $\left(\mathrm{m}^{-2}\right)$ & 3 & 15 & 0.001 & 30 & 26 & 0.001 & 90 & 31 & 0.001 \\
\hline Depth $(\mathrm{cm})$ & 3 & 18 & 0.001 & 30 & 36 & 0.001 & 90 & 27 & 0.001 \\
\hline Air temperature $\left({ }^{\circ} \mathrm{C}\right)$ & 3 & 9 & 0.001 & 30 & 81 & 0.001 & 90 & 11 & 0.001 \\
\hline $\mathrm{DO}\left(\mathrm{mg} \mathrm{L}^{-1}\right)$ & 3 & 10 & 0.001 & 27 & 55 & 0.001 & 61 & 34 & 0.001 \\
\hline Conductivity $\left(\mathrm{mS} \mathrm{cm}^{-1}\right)$ & 3 & 53 & 0.001 & 28 & 18 & 0.001 & 64 & 28 & 0.001 \\
\hline Water temperature $\left({ }^{\circ} \mathrm{C}\right)$ & 3 & 1 & 0.01 & 30 & 95 & 0.001 & 90 & 4 & 0.001 \\
\hline $\mathrm{pH}$ & 3 & 3 & 0.001 & 27 & 77 & 0.001 & 61 & 19 & 0.001 \\
\hline
\end{tabular}

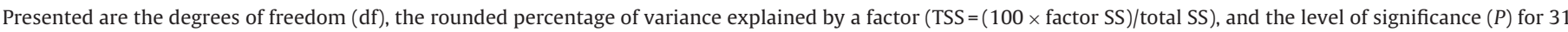
sample dates common to all sites. Air temperature was recorded only at the first transect at each site. 
Table 3

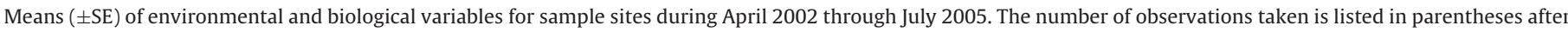
each mean.

\begin{tabular}{|c|c|c|c|c|}
\hline \multirow[t]{2}{*}{ Variable } & \multicolumn{4}{|l|}{ Sample site ${ }^{a}$} \\
\hline & Cork & FEC & LoxSW & LoxVC \\
\hline Water temperature $\left({ }^{\circ} \mathrm{C}\right)$ & $22.2 \pm 0.4 \mathrm{a}(116)$ & $20.9 \pm 0.4 \mathrm{~d}(124)$ & $21.8 \pm 0.4 \mathrm{~b}(100)$ & $21.4 \pm 0.4 \mathrm{c}(132)$ \\
\hline $\mathrm{DO}\left(\mathrm{mg} \mathrm{L}^{-1}\right)$ & $2.1 \pm 0.1 \mathrm{a}(116)$ & $0.9 \pm 0.1 \mathrm{c}(120)$ & $1.9 \pm 0.1 \mathrm{a}(100)$ & $1.6 \pm 0.1 \mathrm{~b}(132)$ \\
\hline $\mathrm{pH}$ & $6.4 \pm 0.1 \mathrm{c}(112)$ & $6.5 \pm 0.1$ bc $(114)$ & $6.5 \pm 0.05 \mathrm{~b}(90)$ & $6.7 \pm 0.07$ a (120) \\
\hline Conductivity $\left(\mathrm{mS} \mathrm{cm}^{-1}\right)$ & $0.3 \pm 0.005 c(116)$ & $0.19 \pm 0.005 \mathrm{~d}(124)$ & $0.37 \pm 0.01 \mathrm{~b}(100)$ & $0.4 \pm 0.008 \mathrm{a}(132)$ \\
\hline Depth $(\mathrm{cm})$ & $85.6 \pm 3.0 \mathrm{a}(116)$ & $65.1 \pm 4.1 \mathrm{c}(124)$ & $37.3 \pm 2.2 \mathrm{~d}(100)$ & $76.6 \pm 2.1 \mathrm{~b}(132)$ \\
\hline Depth change $(\mathrm{cm})^{\mathrm{b}}$ & $21.3 \pm 2.3 \mathrm{~b}$ & $35.7 \pm 3.3 \mathrm{a}$ & $14.4 \pm 1.5 \mathrm{c}$ & $15.4 \pm 1.3 \mathrm{c}$ \\
\hline S. minima biomass $\left(\mathrm{g} \mathrm{DW} \mathrm{m}^{-2}\right)$ & $20.9 \pm 2.2 \mathrm{~b}(116)$ & $23.1 \pm 2.2 \mathrm{~b}(124)$ & $35.5 \pm 3.7 \mathrm{a}(100)$ & $37.3 \pm 3.6 \mathrm{a}(132)$ \\
\hline
\end{tabular}

a Means across rows followed by different letters are significantly different at $P<0.05$ using Tukey's HSD (SAS, 2000).

b Depth change is calculated as the mean change in depth between consecutive samples.

temperature, while the third component ( $11 \%$ variation) reflected a less equivocal complex of wet and dry seasonality characteristics, primarily conductivity and water depth, along with coverage by larger floating plants and larger $S$. minima plants. The fourth principal component was not listed in Table 4 (only $8 \%$ variation explained) but was interpreted as disturbance as measured by the mean change in water depth between sample dates.

Stepwise regression identified conductivity as the most important of several predictive variables for S. minima biomass, which also included the insect herbivores $C$. salviniae and Synclita obliteralis and the abundance of the aquatic plants Spirodela polyrrhiza and Limnobium spongia (Table 5).

\section{Discussion}

Herbivory and interspecific plant abundance appeared to play an important role in explaining the variation in S. minima populations. Therefore, our hypothesis on the importance of herbivory was supported. At the same time, the role of other plant species that occupy the same niche as S. minima is yet unclear. If competition is occurring, it can have profound effects on plants in the presence of herbivory, leading to disproportionate reductions in biomass and other measures of fitness (Center et al., 2005). The influence of these and other biotic factors may depend on the characteristics of the physical environment (Brooker and Callaghan, 1998). In this study, the range of these physical forces was reflected in the seasonality of southern Florida primarily through temperature, and secondarily through depth and conductivity. This included water depth which was lower during the dry season $(63.2 \pm 2.04 \mathrm{~cm}$ [dry]

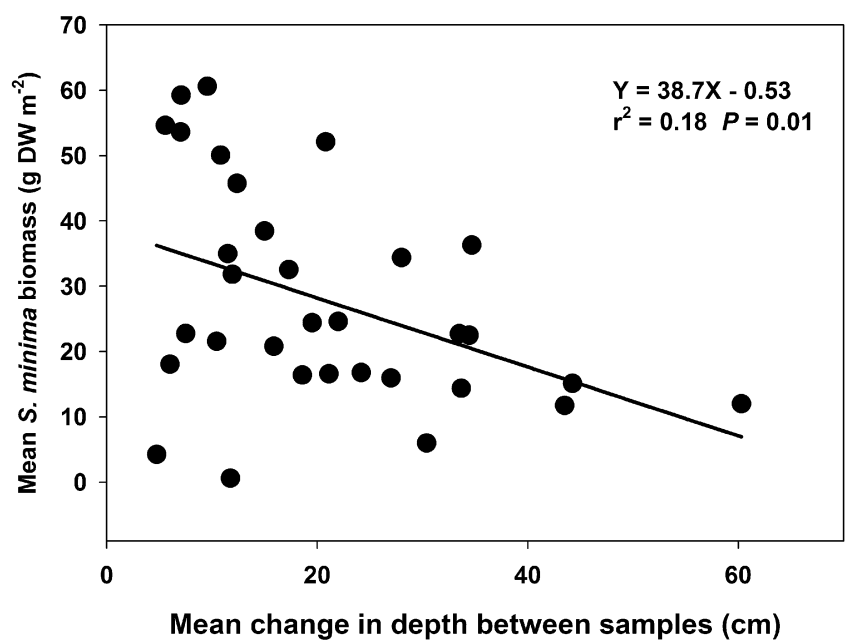

Fig. 1. Relationship between the mean percent change in water depth between samples and S. minima biomass.

vs. $72.4 \pm 2.7 \mathrm{~cm}$ [wet]; $\left.t_{474}=2.72, P<0.006\right)$ to the point where some areas became temporarily stagnant. Mean $( \pm \mathrm{SE})$ conductivity was concomitantly higher during this time $\left(0.32 \pm 0.01 \mathrm{mS} \mathrm{cm}^{-1}\right.$ [dry] vs. $0.29 \pm 0.01 \mathrm{mS} \mathrm{cm}^{-1}$ [wet]; $t_{426}=2.4, P<0.01$ ).

Changes in depth, as measured between sampling periods not seasons, was another physical force with important consequences for small floating plants like S. minima, as evidenced by reduced biomass with greater changes in depth (Fig. 1). The hydrologically

Table 4

Correlations of abiotic and biotic variables ${ }^{\mathrm{a}}$ in four sites in southern Florida with the first three components of a principal component analysis (56\% explained variance).

\begin{tabular}{|c|c|c|c|}
\hline $\begin{array}{l}\text { Principal component }{ }^{\mathrm{b}} \text { (\% } \\
\text { of variance explained) }\end{array}$ & PC1 (27\%) & PC2 (17\%) & PC3 (12\%) \\
\hline Air temperature & -0.09 & 0.79 & 0.27 \\
\hline Dissolved oxygen & -0.19 & -0.75 & 0.07 \\
\hline Salinity & 0.17 & -0.16 & -0.65 \\
\hline Water temperature & -0.15 & 0.85 & 0.17 \\
\hline Depth & 0.08 & 0.05 & 0.72 \\
\hline S. minima coverage & -0.69 & 0.02 & -0.18 \\
\hline S. polyrrhiza coverage & 0.87 & -0.03 & -0.15 \\
\hline L. spongia coverage & -0.09 & 0.18 & 0.72 \\
\hline No. C. salviniae per g of S. minima & 0.54 & 0.09 & 0.20 \\
\hline No. S. obliteratis per g of S. minima & 0.82 & 0.01 & 0.03 \\
\hline Percentage of S. minima buds damaged & 0.51 & 0.16 & 0.11 \\
\hline Size of $S$. minima leaves & 0.26 & -0.03 & 0.59 \\
\hline
\end{tabular}

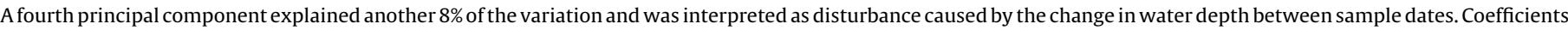
greater than \pm 0.4 are considered informative and shown in bold. Variables with coefficients less than \pm 0.4 in any of these three principal components are omitted.

a Omitted variables: $\mathrm{pH}$, flow rate, change in depth between samples, coverage of $E$. crassipes, $P$. stratiotes, and A. caroliniana, percentage of the $S$. minima mat that was

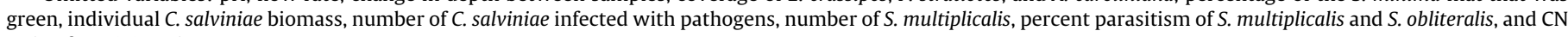
ratio of $S$. minima tissue.

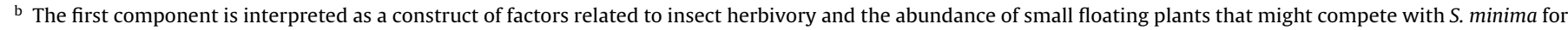
space, the second to temperature, and the third to a combination of seasonal influences on water quality as well as the abundance of larger plant species. 
Table 5

Stepwise forward regression of S. minima biomass across all sites with independent abiotic and biotic variables.

\begin{tabular}{|c|c|c|c|c|c|}
\hline Dependent & Step & Independent variable & $r^{2}$ & $p$ & Slope \\
\hline \multirow[t]{7}{*}{ S. minima biomass } & 1 & Conductivity & 0.13 & 0.0001 & 115.17 \\
\hline & 2 & No. C. salviniae & 0.22 & 0.0001 & 0.31 \\
\hline & 3 & Coverage by S. polyrrhiza & 0.29 & 0.0001 & -0.50 \\
\hline & 4 & No. O. obliteralis & 0.35 & 0.0001 & 0.09 \\
\hline & 5 & Coverage by L. spongia & 0.39 & 0.0001 & -0.56 \\
\hline & 6 & Air temperature & 0.41 & 0.002 & -1.29 \\
\hline & 7 & Water depth & 0.42 & 0.005 & 0.13 \\
\hline
\end{tabular}

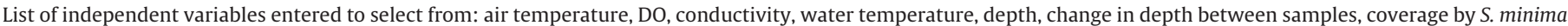

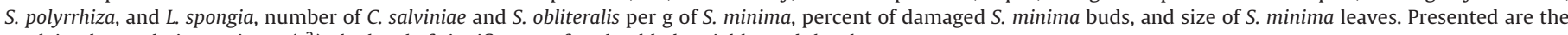
explained cumulative variance $\left(r^{2}\right)$, the level of significance of each added variable, and the slope.
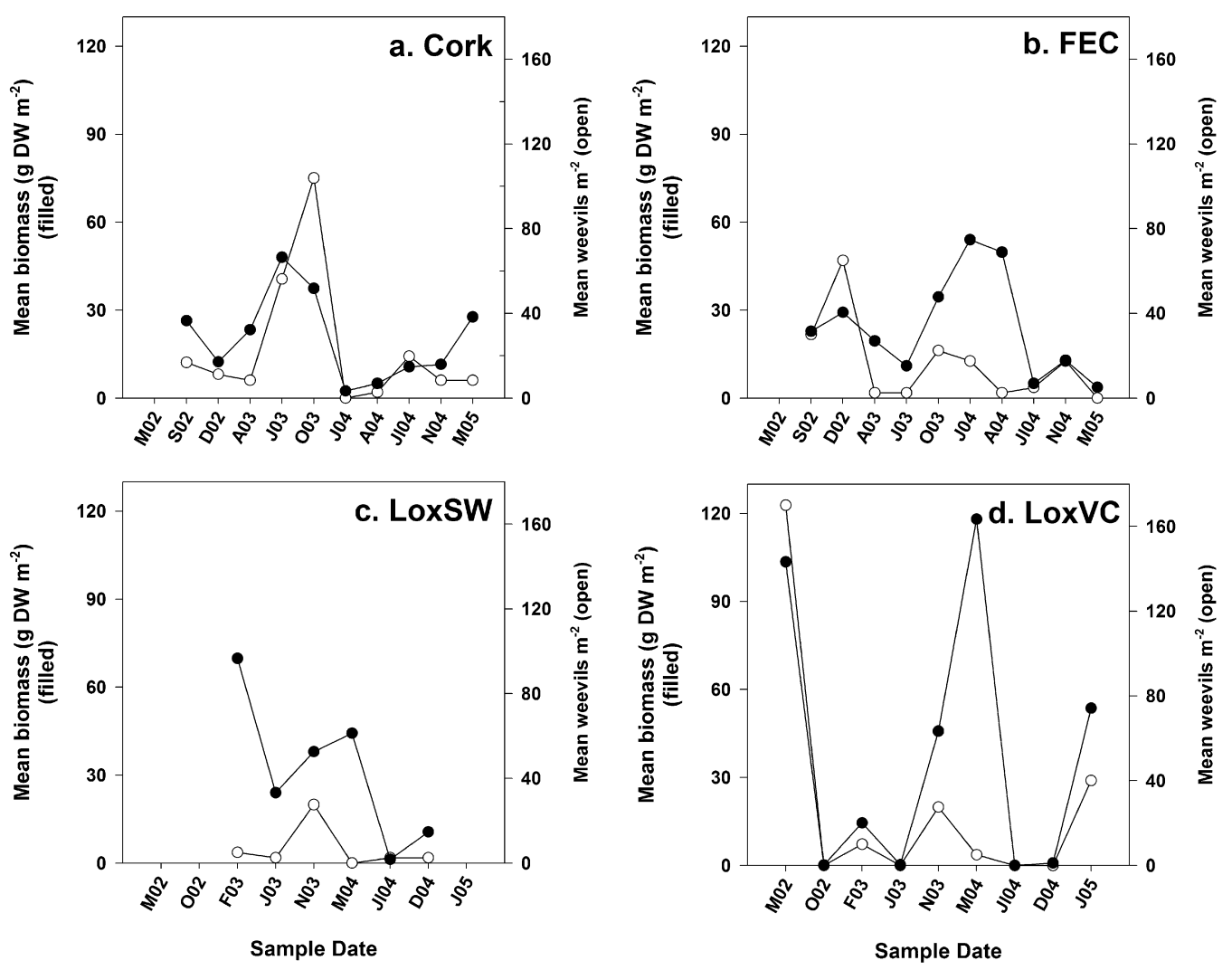

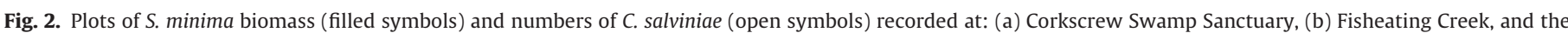
Arthur R. Marshall Loxahatchee National Wildlife Refuge sites (c) Swamp, and (d) Visitor's Center. Some dates have been omitted to improve legibility.

more variable sites like Cork and FEC had less S. minima (Table 3). Seasonality was linked to changes in depth with a $28.2 \pm 3.2 \%$ mean monthly change during the dry season compared with a $67.3 \pm 9.3 \%$ change during the wet season $\left(t_{462}=4.1, P<0.0001\right)$. Although more stagnant conditions promoted greater biomass densities, these relatively immobile plant populations did not experience higher levels of herbivory, neither from $C$. salviniae $(P=0.48)$ whose adults are more likely to disperse locally by walking on mats rather than flying, nor from defoliators whose adults readily fly $(P=0.77)$. Instead, weevil numbers appeared to roughly track $S$. minima biomass at all sites regardless of the disturbance caused by changes in depth (Fig. 2).

Although we did find Nosema sp. pathogens in C. salviniae in two consecutive sample dates (August-September, 2003) at one site (LoxVC), the amount of infection was considered to be very light (G. White, personal communication). This is not the first record of pathogen infection for this species: White et al. (2007) found a parasitic alga, Helicosporidium sp., in a shipment of $C$. salviniae from South Africa. Therefore, it appears unlikely that pathogens may periodically weaken populations of $C$. salviniae and thereby indirectly influence $S$. minima populations.

This study documented population cycles of S. minima in southern Florida in response to a shifting array of abiotic and biotic factors. The hierarchy of their importance was less clear although the importance of herbivory as a biotic factor was apparent. Salvinia minima populations, with their ability to grow quickly, move passively, and grow in shaded conditions were found to be fairly resilient across time and space.

\section{Acknowledgment} ing.

We thank Eileen Pokorny for her assistance in sample process-

\section{References}

Brooker, R.W., Callaghan, F.V., 1998. The balance between positive and negative interactions and its relationship to environmental gradients: a model. Oikos 81 , 196-201. 
Center, T.D., Van, T.K., Dray, F.A., Franks, S.J., Rebelo, M.T., Pratt, P.D., Rayamajhi, M.D., 2005. Herbivory althers competitive interactions between two invasive aquatic plants. Biological Control 33, 173-185.

Grime, J.P., 1973. Competitive exclusion in herbaceous vegetation. Nature 242, $344-347$.

Harpole, W.S., Suding, K.N., 2007. Frequency-dependence stablilizes competitive interaction among four annual plants. Ecology Letters 10, 1164-1169.

Jacono, C.C., Davern, T.R., Center, T.D., 2001. The adventive status of Salvinia minima and S. molesta in the southern United States and the related distribution of the weevil Cyrtobagous salviniae. Castanea 66, 214-226.

Kissinger, D.G., 1966. Cyrtobagous Hustache, a genus of weevils new to the United States fauna (Coleoptera Curculionidae: Bagoini). Coleoptra Bulletin 20, 125-127.

Mickel, J.T., Beitel, J.M., 1988. Pteridophyte flora of Oaxaca, Mexico. Memoirs of the New York Botanical Garden 46, 328-329.

Room, P.M., Harley, K.L.S., Forno, I.W., Sands, D.P.A., 1981. Successful biological control of the floating weed salvinia. Nature $294,78-80$.
SAS Institute 2000. SAS System for Regression, 3rd edition. SAS Institute Inc., Cary NC, USA.

Small, J.K., 1931. Ferns of Florida: Being Description of and Notes on the Fern-Plant Growing Naturally in Florida (illustrated). The Science Press, NY.

Stoltze, R.G., 1983. Ferns and fern allies of Guatemala. Part III. Marsileaceae, Salviniaceae, and the fern allies. Field of Botony 12, 10-13.

Tipping, P.W., Bauer, L., Martin, M.R., Center, T.D., 2009. Competition between Salvinia minima and Spirodela polyrrhiza mediated by nutrient levels and herbivory. Aquatic Botony 90, 231-234.

Webb, C.O., Gilbert, G.S., Donoghue, M.J., 2006. Phylodiversity dependent seedling mortality, size structure, and disease in a Bornean rain forest. Ecology 87, S123-S131.

White, S.E., Tipping, P.W., Becnel, J.J., 2007. First isolation of a Helicosporidium sp. (Chlorophyta Trebouxiophyceae) from the biological control agent Cyrtobagous salviniae (Coleoptera: Curculionidae). Biological Control 40, 243-245. 